industrial training boards, and the industrial training officers. This is no time to lament the inability of a voluntary organization, like the British Association for Commercial and Industrial Education, to recruit enough members for its second industrial training officers' course. Such men are essential and the Ministers of Labour and Education should at once get together to launch a fullscale training course along the lines so successfully carried out for youth employment officers. With the right conditions and appeal there should be no shortage of recruits. A national lead of this sort would find such a response in industry and education that, in one decade, the workers' readiness to accept and even initiate change could surprise all who are unfamiliar with existing training schemes in iron and steel and ehemical companies. Training will come into its own when it is recognized as the handmaiden of productivity. Science will only be applied in industry and commerce when men and women are prepared to receive it; the ways of science have to be taught; but there are some in authority who cannot, or will not, learn.

\section{CHRISTIANITY AND SCIENCE}

\section{Faith and Reason}

By Nathaniel Micklem. Pp. 196. (London: Gerald Duckworth and Co., Ltd., 1963.) 158.

\section{$\mathrm{T}$} HE problem of communication between various disciplines of learning is by no means easy to solve. A man ought to be fully briefed in both if he has something to say to those on one side or the other. If not he must have a real sympathy with what others are trying to do. Dr. Micklem is not a man of science in the accepted sense of the word, but he is a man of the kind of sympathy required. At least he is aware of what men of science are doing and of the importance of their work. $\mathrm{He}$ has philosophical learning and a long experience of dealing with human beings, and he writes with lucidity and charm. His book is an attempt to present an interpretation of Christian thinking to intellectual men and women, recognizing the notable advances in science, the new knowledge of non-Christian religions, the rise of Marxism, the resurgence of cruelty and violence, and the thinking within Christianity itself about its meaning and message. Himself a poet, he also quotes most effectively from poetry and literature to illustrate his themes.

The first part of the book is a study of Nature, of values and of religion and truth. - Dr. Micklem concludes that Nature is a series of inter-connected patterns of unimaginable range and complication. It is inconceivable that all this occurs by chance. It is equally inconceivable that rational creatures should emerge from a universe that is itself irrational. Pattern is correlative to intelligence. There is reason to believe in an Intelligent Ground to all that is. It is rational man that also ascribes values as well as recognizing patterns. He then shows that something new has emerged in the planet, like the emergence of life or that of man. This is what he calls the Christevent.

What was the truth of this event? What does it mean? This raises questions of history and of faith, and as well in our own time those of language. "The use of language not really intelligible or convincing to the minds of our contemporaries is very serious hindrance to the acceptance of the Christian faith"; and later: "The Christian doctrine of the Godhead must not be unintelligible to all except professionals". "God is personal Love embracing His creation. If this were made plain to the ordinary Christian and to the world outside the understanding and presentation of Christianity would be much simpler." Dr Micklem would be the first to admit that even when so presented
Christianity does not necessarily convince many intelligent men who cannot bring themselves to conceive that it can be true, but at least his book does make a brave attempt to present it in such a way that some who are rejecting a false image of it may take a new look at what is involved in it and perhaps find it less irrational than at first they thought it to be.

There are hard demands on the reader in the examination of Christology-the doctrine of the person of Christ. The reference to Teilhard de Chardin on pp. 120-121 shows one way in which a man of science understood the meaning of Christ in the long evolutionary development of mankind. In the same way as he discusses the Christevent Dr. Micklem explains the meaning of reconciliation. "The Biblical and theological phrase 'to be in a state of grace' can most readily be understood as the opposite of being in disgrace." But when all is said and done to communicate the Christian religion intelligently the entry into the Kingdom is still not easy. It is peculiarly hard for intellectuals, he says. "The Gospel is very simple: it is apprehended by the illuminated Reason not by reasoning. Faith is an immediate perception, not the conclusion of a syllogism."

In view of the fact that so many intellectuals reject Christianity owing to the weight of the evil and pain in the world it is satisfying that Dr. Micklem looks at this whole problem, as he calls it "the great enigma". In the end he has no simple solution except that what we do not know must somehow be consonant with what we know. We cannot judge of the pattern until it is completed. On this and on many other questions which cannot find obvious answers Dr. Micklem writes with a kind of reverent agnosticism which typifies one aspect of the Christian religion, for on some matters we see through a glass darkly, and not yet face to face. In the end we have to move from the "finite, speculative and transient into the dimension of the infinite, the real, and the eternal. God is in heaven and thou upon earth; therefore let thy words be fow".

This is not a book for those who like everything 'cut and dried'. This is because Dr Micklem knows that one cannot cut and dry the ultimate reality with which he is in contact. It is not unlike the Bishop of Woolwich's book Honest to God in spirit; but it is the book of an old man reflecting on a long experience and thinking aloud. One hopes it will be read by some of those intelligent people who do not dismiss religion as an illusion, but have not so far found what they can call a reasonable faith. Let them at least consider what Dr. Micklem has to say. Marcus KNight

\section{SEEING CAUSAL EVENTS}

\section{The Perception of Causality}

(Methuen's Manuals of Modern Psychology.) By Prof. A. Michotte. Pp. xxii + 425. (London : Methuen and Co., Ltd., 1963.) $45 s$.

DROF. and Mrs. T. R. Miles are to be congratulated on their excellent translation of this classical work, previously available only in the French editions of 1946 and 1955. This new edition is not only a translation into clear English (a very difficult task), but it also contains a summary and critical essays by Prof. Miles, as well as a really helpful introduction by Prof. R. C. Oldfield, who has known the author during the period of these researches, and manages to convey something of the atmosphere of Michotte's laboratory at Louvain.

What Michotte has done is to point out that we see some events as causal. This is not so for all the things we believe to be causal-if wheat is planted we know that this causes the crop to come up some months later, but the connexion between these events is not apparent in direct perception. On the other hand (and this is what 